Research Article

\title{
Genotoxicity of titanium dioxide nanoparticles and triggering of defense mechanisms in Allium cepa
}

\author{
Ronaldo dos Santos Filho ${ }^{1 *}$, Taynah Vicari ${ }^{1 *}$, Samuel A. Santos ${ }^{2}$, Karoline Felisbino ${ }^{1}$, Ney Mattoso ${ }^{3}$, Bruno \\ Francisco Sant'Anna-Santos ${ }^{4}$, Marta Margarete Cestari ${ }^{1}$ (iD and Daniela Morais Leme ${ }^{1}$ (iD \\ ${ }^{1}$ Department of Genetics, Universidade Federal do Paraná (UFPR), Curitiba, PR, Brazil. \\ ${ }^{2}$ Department of Plant Pathology, Universidade Federal de Viçosa (UFV), Viçosa, MG, Brazil. \\ ${ }^{3}$ Department of Physics, Universidade Federal do Paraná (UFPR), Curitiba, PR, Brazil. \\ ${ }^{4}$ Department of Botany, Universidade Federal do Paraná (UFPR), Curitiba, PR, Brazil.
}

\begin{abstract}
Titanium dioxide nanoparticles ( $\left.\mathrm{TiO}_{2} \mathrm{NPs}\right)$ are widely used and may impact the environment. Thus, this study used a high concentration of $\mathrm{TiO}_{2} \mathrm{NP}(1000 \mathrm{mg} / \mathrm{L})$ to verify the defense mechanisms triggered by a plant system - an indicator of toxicity. Furthermore, this study aimed at completely characterizing $\mathrm{TiO}_{2} \mathrm{NP}$ suspensions to elucidate their toxic behavior. $\mathrm{TiO}_{2} \mathrm{NPs}$ were taken up by meristematic cells of Allium cepa, leading to slight inhibition of seed germination and root growth. However, severe cellular and DNA damages were observed in a concentration-dependent manner $(10,100$, and $1000 \mathrm{mg} / \mathrm{L})$. For this reason, we used the highest tested concentration $(1000 \mathrm{mg} / \mathrm{L})$ to verify if the plant cells developed defense mechanisms against the $\mathrm{TiO}_{2} \mathrm{NPs}$ and evaluated other evidences of $\mathrm{TiO}_{2} \mathrm{NP}$ genotoxicity. Nucleolar alterations and plant defense responses (i.e., increased lytic vacuoles, oil bodies and NP phase change) were observed in meristematic cells exposed to $\mathrm{TiO}_{2} \mathrm{NP}$ at $1000 \mathrm{mg} / \mathrm{L}$. In summary, $\mathrm{TiO}_{2} \mathrm{NPs}_{\mathrm{s}}$ can damage the genetic material of plants; however, plants displayed defense mechanisms against the deleterious effects of these NPs. In addition, $A$. cepa was found to be a suitable test system to evaluate the cyto- and genotoxicity of NPS.
\end{abstract}

Keywords: Chromosomal aberrations, micronuclei, nucleolar alterations, cellular alterations, nanoparticle phase-change.

Received: July 11, 2018; Accepted: November 5, 2018.

\section{Introduction}

Titanium dioxide nanoparticles $\left(\mathrm{TiO}_{2} \mathrm{NPs}\right)$ are among the most used manufactured nanomaterials, being produced in thousands of tons per year around the world (Robichaud et al., 2009). This NP occurs in three forms in nature: anatase, brookite, and rutile (Clement et al., 2013). The frequent use of products containing $\mathrm{TiO}_{2} \mathrm{NPs}$ has been associated with inappropriate disposal of domestic and industrial effluents, which may result in the release of this NP into the environment. Thus, there is an emerging concern about the environmental impacts caused by NPs (Monica and Cremonini, 2009), in particular $\mathrm{TiO}_{2} \mathrm{NPs}$.

Considering that higher plants are suitable models for assessing environmental toxicants and plants are fundamental organisms of all ecosystems, phytotoxicity studies become relevant because: (1) plants are considered the basis of the food chain; (2) plants provide the oxygen neces-

Send correspondence to Daniela Morais Leme. Department of Genetics, Universidade Federal do Paraná, Avenida Coronel Francisco H. dos Santos, s/n, Jardim das Américas, 81531-970, Curitiba, PR, Brazil, Phone: +55 41 3361-1727; Fax: +55 41 3361-1793. E-mail: daniela.leme@ ufpr.br.

*The first two authors participated equally in this research. sary for life; and (3) plants are distributed in different environments (terrestrial and aquatic). Thus, damages to plants can generate an imbalance in the ecosystems, emphasizing the importance of phytotoxicity studies (Ma et al., 2010). Within this context, there is a concern about the toxicological impacts of NPs on living organisms, such as plants - target organisms of NPs through different environment compartments (air, water, and soil).

The toxic effects of $\mathrm{TiO}_{2} \mathrm{NPs}$ on plants have been reported in the literature (Ghosh et al., 2010; Klancnik et al., 2010; Pakrashi et al., 2014). However, these studies considered only the nanopowder form, without an adequate characterization of $\mathrm{TiO}_{2} \mathrm{NPs}$ suspensions, fundamental to understanding the internalization, bio-uptake, and the behavior of the $\mathrm{TiO}_{2} \mathrm{NPs}$ inside the cells.

Allium cepa is an efficient plant system that has some advantages over other higher plants, in particular regarding its convenient chromosomal features that allow the evaluation of genetic damages. Genotoxic effects of different contaminants have already been reported in the literature using A. cepa (Grisolia et al., 2005; Rodrigues et al., 2010; Dourado et al., 2017), including the identification of the 
mechanisms of action (Fiskesjo, 1985; Leme and MarinMorales, 2009; Klancnik et al., 2010; Pakrashi et al., 2014).

Moreover, plant systems allow the performance of complementary analysis. Ag-NOR banding technique is a new method to detect a genotoxicity biomarker used in $A$. cepa that has shown to be an efficient tool for studying these effects caused by contaminants (Mazzeo and MarinMorales, 2015). These authors reported changes in AgNOR banding that may suggest aneugenic effects or increased genomic activity. Furthermore, Zhao et al. (2016) observed a cellular defense mechanism and morphological damages (e.g., ruptures of the plasma membrane, the appearance of oil bodies, and changes in the vacuoles).

Thereby, this study aimed to evaluate the toxic potential of $\mathrm{TiO}_{2} \mathrm{NPs}$ in higher plants to provide knowledge about the cellular responses after $\mathrm{TiO}_{2} \mathrm{NPs}$ exposure. For this purpose, several biomarkers of toxicity in $A$. серa test system (e.g., germination rate and root development, morphological and DNA damages, nucleolar alterations) were used. In addition, selected area electron diffraction (SAED) analysis was carried out to verify NP phase-change as a plant defense mechanism.

\section{Material and Methods}

\section{Chemical characterization of the titanium dioxide nanoparticle suspensions}

The $\mathrm{TiO}_{2} \mathrm{NP}$ (powder) was purchased from SigmaAldrich $^{\circledR}\left(\right.$ CAS n $\left.^{\circ} 1317-70-0\right)$, with physical characteristics being a particle size $21 \mathrm{~nm}$ (TEM), $\geq 99.5 \%$ trace metal basis, and $100 \%$ anatase. Morphological characteristics of the $\mathrm{TiO}_{2} \mathrm{NP}$ powder were also determined to verify the crystalline structure by X-ray diffraction, the specific surface area by Brunauer-Emmett-Teller Theory (BET), and the surface chemistry using the X-ray photoelectron spectroscopy (XPS).

The $\mathrm{TiO}_{2} \mathrm{NP}$ was evaluated regarding its toxic potential using the Allium test system at 10,100, and $1000 \mathrm{mg} / \mathrm{L}$. The choice of the highest concentration used in this study was defined based on other studies (Klancnik et al., 2010; Zhu et al., 2010). $\mathrm{TiO}_{2} \mathrm{NP}$ suspensions were prepared in ultrapure water and dispersed in an ultrasonic water bath $(42.000 \mathrm{~Hz}, 160 \mathrm{~W})$ for $30 \mathrm{~min}$ immediately before the start of the bioassays with $A$. серa. The highest concentration (1000 mg/L) was also chosen to observe if the cells developed defense mechanisms, what would be an indication of toxicity, and to observe the internalization, bio-uptake, and behavior of the $\mathrm{TiO}_{2} \mathrm{NPs}$ inside the cells.

The $\mathrm{TiO}_{2} \mathrm{NPs}$ suspensions were also analyzed. The characterization of these suspensions was performed by the Zetasizer $^{\circledR}$ Nano Series ZS90 (Malvern Instruments, Worcestershire, UK) to determine the average particle size (dynamic light scattering - DLS), polydispersity index and zeta potential (Laser Doppler Velocimetry and electrophoresis -
LDV). We considered an angle of $90^{\circ}$ and a wavelength of $633 \mathrm{~nm}$ (Malvern, 2015).

A complementary analysis of the NPs structure was performed by the selected area electron diffraction (SAED) technique, as described below).

\section{Test system and exposure condition}

One hundred $A$. cepa seeds ( $2 \mathrm{n}=16$ chromosomes $)$ of the same batch and variety (the "baia periform" onion) were submitted to germination with the $\mathrm{TiO}_{2} \mathrm{NP}$ suspensions $(10,100$, and $1000 \mathrm{mg} / \mathrm{L})$, ultrapure water as negative control (NC), $10 \mathrm{mg} / \mathrm{L}$ of methyl methane sulfonate (MMS; Sigma-Aldrich, CAS 66-27-3) as positive control (PC) for cyto- and genotoxicity testing, and zinc sulfate heptahydrate (Sigma-Aldrich ${ }^{\circledR}$, CAS 7446-20-0) at $6 \mathrm{mg} / \mathrm{mL}$ (PC for seed germination and root elongation toxicity test) in polystyrene Petri dishes (diameter $85 \mathrm{~mm}$ ) covered with a nylon net (100 seeds/plate) (Leme and Marin-Morales, 2008). $\mathrm{TiO}_{2} \mathrm{NP}$ suspensions were replaced by fresh ones every $24 \mathrm{~h}$ to assure its bioavailability for the test system.

All experiments were carried out at $25^{\circ} \mathrm{C}$ in the dark. The seed germination and root elongation toxicity tests were performed using triplicate plates per treatment (100 seeds/plate), while the other assays were carried out using a single plate per treatment (Lin and Xing, 2007; Leme and Marin-Morales, 2008).

\section{Seed germination and root elongation toxicity test}

The seed germination and root elongation toxicity tests were carried out according to the protocol described by Rank (2003). After 5 days of exposure, seed germination (number of seedlings) and root length were measured. Toxicity was expressed as the difference of seed germination and root elongation when compared to the NC. The results were statistically analyzed using a Shapiro-Wilk test followed by Student's $t$-test $(p<0.05)$.

\section{Cyto- and genotoxicity assessments}

Allium cepa roots of $2 \mathrm{~cm}$ in length ( $\sim 5$ days) were fixed in a mixture of ethanol and acetic acid $(3: 1-\mathrm{v} / \mathrm{v}$, Merck). The fixed roots were stained with Schiff's reagent, as described by Feulgen and Rossenbeck (Mello and Vidal, 1978), and the slides were prepared using the meristematic region according to the protocol described by Leme and Marin-Morales (2008).

Cytotoxicity was assessed by recording the changes in the mitotic index (MI) of the meristematic cells. Genotoxicity was determined by scoring different types of chromosomal aberrations (CAs) and nuclear abnormalities (NAs). Micronucleated cells were also scored to determine the mutagenicity (Leme and Marin-Morales, 2008). Additionally, the mode of action of $\mathrm{TiO}_{2} \mathrm{NP}$ was defined based on the analysis of different types of CAs, which were grouped as clastogenic (chromosome bridges and breaks) 
or aneugenic (chromosomal losses, chromosomal delay) according to Leme et al. (2008).

These parameters were evaluated under a light microscope (Olympus BX-40- magnification - $400 \mathrm{x}$ ) and 10 slides per treatment were analyzed (500 cells/slide). The treatments were statistically compared using the non-parametric Kruskal-Wallis test followed by the Student-Newman-Keuls test $(p<0.05)$.

\section{Complementary tests}

Complementary tests to the genotoxicity test were performed to confirm the toxic effects of $\mathrm{TiO}_{2} \mathrm{NP}$ and to visualize its behavior inside the cells.

In order to perform these tests, only the highest concentration $(1000 \mathrm{mg} / \mathrm{L})$ was chosen, because this concentration had already been shown to be genotoxicologically toxic, and the current objective was to confirm the toxicity and observe the effects caused to the plant system by the $\mathrm{TiO}_{2} \mathrm{NPs}$.

\section{Silver-stained nucleoli and nucleolar organizer region (Ag-NOR)}

Ag-NOR staining and nucleoli analysis were carried out using fixed roots of $1000 \mathrm{mg} / \mathrm{L} \mathrm{TiO}_{2} \mathrm{NP}$ treatment and an $\mathrm{NC}$ group, according to the previous protocol described by Mazzeo and Marin-Morales (2015). Thus, this analysis was used to verify whether the nucleolar pattern was altered after $\mathrm{TiO}_{2} \mathrm{NP}$ exposure.

Images were obtained using a motorized Axio Imager Z2 epifluorescence microscope (Carl Zeiss, Jena, Germany), equipped with an automated scanning $\mathrm{V}$ Slide (Metasystems, Altlussheim, Germany). Five thousand cells of both treatments were analyzed. This analysis was performed only on A. cepa interphase cells. The number of nucleoli per cell was determined by the counting tool implemented in Anati-Quanti software (Aguiar et al., 2007), and their size was determined by Image $\mathrm{J}$ using a specific tool that measures the area of each nucleolus (Passoni et al., 2014). The results were statistically analyzed using a Shapiro-Wilk test followed by a Student's $t$-test $(p<0.05)$.

\section{Morpho-anatomical analysis}

Onion roots of $2 \mathrm{~cm}$ in length ( $\sim 5$ days) were fixed in Karnovsky solution (Karnovsky, 1965) for light microscopy (LM) and transmission electron microscopy (TEM) analyses. For both methodologies, visual analysis was performed.

\section{Light microscopy (LM)}

Fixed roots were dehydrated with ethanol, embedded in acrylic resin (methacrylate) and cut into $5 \mu \mathrm{m}$ longitudinal sections (manual rotary microtome, Reichert). Sections were stained with toluidine blue stain at $\mathrm{pH} 4.0$ (O'Brien and McCully, 1981) and the slides were sealed using Entellan ${ }^{\circledR}$. Photographs of the stained sections were taken using a LM Zeiss Axioskop 2 equipped with a digital camera (MRC3). Five slides per treatment were analyzed.

\section{Transmission electron microscopy (TEM)}

Onion roots of $2 \mathrm{~cm}$ in length ( $\sim 5$ days) fixed in Karnovsky solution were rinsed in $0.05 \mathrm{M}$ cacodylate buffer $(3 \times$ for $10 \mathrm{~min})$ and post-fixed in $1 \%$ osmium tetroxide for $1 \mathrm{~h}$. The samples were contrasted with uranyl acetate at $0.5 \%-\mathrm{v} / \mathrm{v}$ (overnight), dehydrated in acetone and embedded in resin (SPURR). After polymerization, ultrathin sections $(70 \mathrm{~nm})$ were placed on copper grids (300 mesh), counterstained with uranyl acetate and lead citrate (Reynolds, 1963), and observed under TEM (Jeol, JEM $1200 \mathrm{EX}-\mathrm{II})$ operating at $80 \mathrm{kV}$ to avoid sample damage. The images were digitally captured by a CCD camera Gatan model Orius SC1000B.

\section{Selected area electron diffraction (SAED)}

Analyses of the $\mathrm{TiO}_{2} \mathrm{NP}$ crystal structure were made using the SAED technique with TEM (Jeol, JEM 1200EX II), and the electron diffraction figures were captured by a CCD Orius SC1000B camera. To determine the interplanar spacing of the crystal structure, the following expression was used: $\mathrm{d}(\mathrm{nm})=\lambda \mathrm{L}(\mathrm{nmpx}) / \mathrm{D}(\mathrm{px})$. In this formula, when measuring the distance (D) from the diffracted point to the center of the transmitted beam and knowing the camera constant $(\lambda \mathrm{L})$ and the TEM operating conditions, it is possible to measure the interplanar spacing (d), which defines certain characteristics of the crystalline material present in the sample. To determine the camera constant, which was $51.9 \pm 0.2 \mathrm{~nm}$ pixel, a gold film was used. This technique was applied to $A$. cepa roots exposed to $1000 \mathrm{mg} / \mathrm{L}$ $\mathrm{TiO}_{2} \mathrm{NP}$ suspension to observe NP internalization. Additionally, this analysis was performed with the nanopowder form, obtained from $1000 \mathrm{mg} / \mathrm{L} \mathrm{TiO} 2 \mathrm{NP}$ suspension, before exposure to A. cepa roots.

\section{Results}

\section{Physicochemical characterization of $\mathrm{TiO}_{2} \mathrm{NPS}$}

The nanopowder form was analyzed by transmission electron microscopy, as well as by X-ray diffraction. The analysis showed that the crystal structures of $\mathrm{TiO}_{2} \mathrm{NPs}$ comprise $100 \%$ anatase phase, consisting of $28.42 \%$ titanium and $71.58 \%$ oxygen. The DLS method revealed an average size of $45 \mathrm{~nm}$ and $107 \mathrm{~nm}$ for the aggregated particles, while the BET method showed a specific area of 83.47 $\mathrm{m}^{2} / \mathrm{g}$.

The analysis of the $\mathrm{TiO}_{2} \mathrm{NP}$ suspensions showed that their polydispersity indices were $91.1 \%(10 \mathrm{mg} / \mathrm{L}-\mathrm{pH}$ 5.68), $76.5 \%$ (100 mg/L - pH 5.72), and $57.3 \%(1000 \mathrm{mg} / \mathrm{L}$ - $\mathrm{pH}$ 4.90). The size distribution of the $\mathrm{TiO}_{2} \mathrm{NP}$ suspensions is shown in Figure 1. The zeta potential values ranged from 21.2 to $2.99 \mathrm{mV}$, which confirms their instability. 

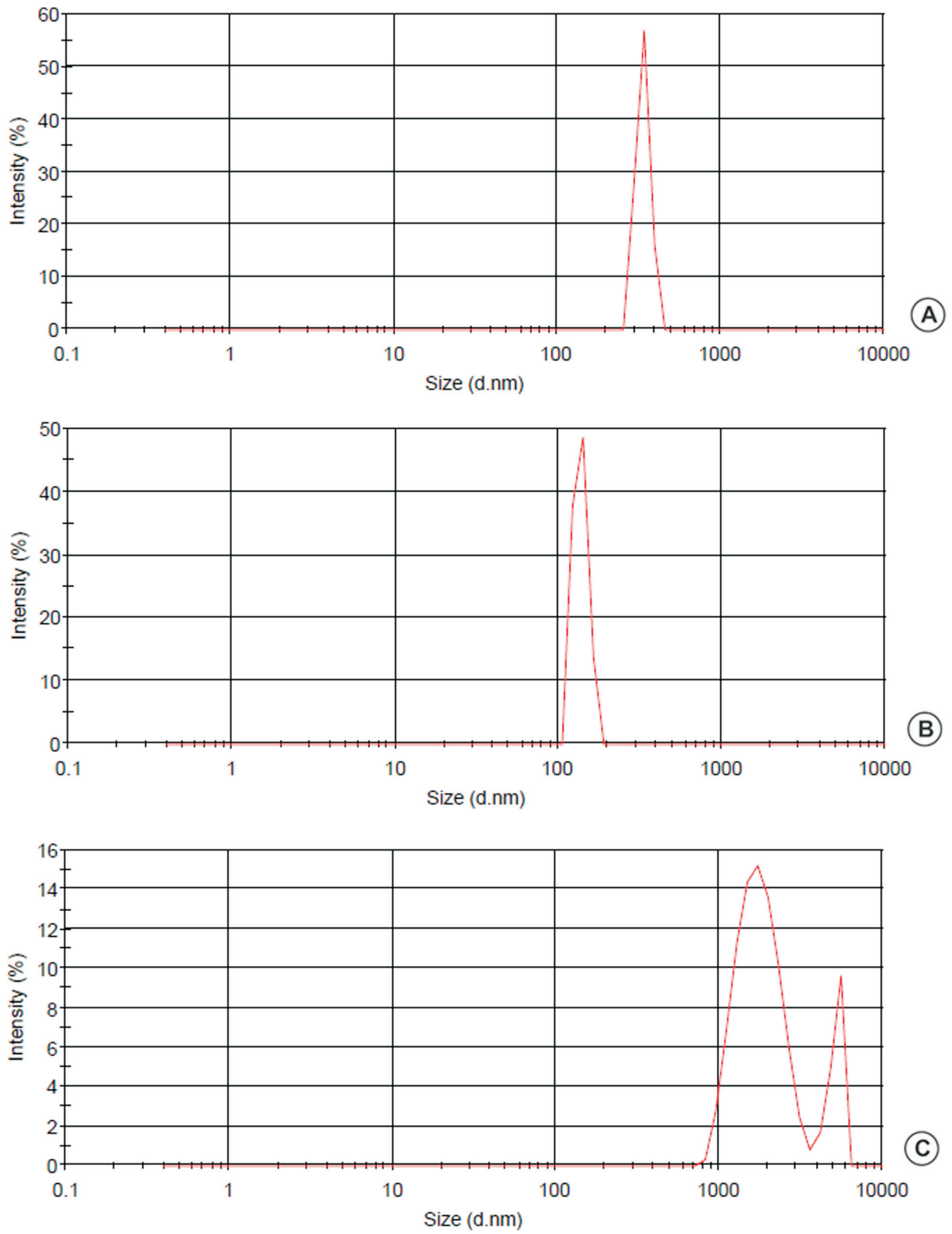

Figure 1 - Intensity and size of $\mathrm{TiO}_{2} \mathrm{NP}$ suspensions tested, showing size distribution of the particles in nanometers. Graphics generated by Zeta Sizer Device (Malvern). (A) $10 \mathrm{mg} / \mathrm{L} \mathrm{TiO}_{2} \mathrm{NP}$, (B) $100 \mathrm{mg} / \mathrm{L} \mathrm{TiO}{ }_{2} \mathrm{NP}$, (C) $1000 \mathrm{mg} / \mathrm{L} \mathrm{TiO}{ }_{2} \mathrm{NP}$.

The SAED pattern analysis of $1000 \mathrm{mg} / \mathrm{L}$ suspension showed that all $\mathrm{TiO}_{2} \mathrm{NPs}$ displayed a tetragonal format, which is a feature of the anatase phase, with an average size of $25 \mathrm{~nm}$. On the other hand, the SAED analysis also revealed that the internalized $\mathrm{TiO}_{2} \mathrm{NP}$ in the vacuole compartment of meristematic cells shows an orthorhombic format, a feature of the brookite phase, with several sizes up to $450 \mathrm{~nm}$.

\section{Seed germination and root elongation toxicity test}

The results of the A. сеpa toxicity test showed a significant reduction in both the germination rate (16-25\%) and root development (11-18\%) for all treatments with $\mathrm{TiO}_{2} \mathrm{NP}$ suspensions (concentration-dependent manner) (Table 1).

\section{Cyto- and genotoxicity assessments}

A. cepa meristematic cells exposed to the $\mathrm{TiO}_{2} \mathrm{NPs}$ suspensions showed a significant reduction in the MI at 100 $\mathrm{mg} / \mathrm{L}$ and $1000 \mathrm{mg} / \mathrm{L}$, and a tendency for the MI to decrease at the $10 \mathrm{mg} / \mathrm{L}$ concentration in a concentration-dependent manner. Significantly higher levels of both CA and MN were also observed after exposure of the A. cepa roots to 
Table 1 - Seed germination and root growth inhibition of Allium cepa test system exposed to titanium dioxide nanoparticles $\left(\mathrm{TiO}_{2} \mathrm{NP}\right)$.

\begin{tabular}{lccc}
\hline Treatment & Concentration & $\mathrm{SG}$ & $\mathrm{RL}$ \\
\hline & $(\mathrm{mg} / \mathrm{L})$ & $\mathrm{M} \pm \mathrm{SD}$ & $\mathrm{M} \pm \mathrm{SD}$ \\
$\mathrm{NC}$ & - & $60 \pm 1$ & $1.93 \pm 0.66$ \\
& 10 & $53.3 \pm 1.15^{*}$ & $1.60 \pm 0.70^{*}$ \\
$\mathrm{TiO}_{2} \mathrm{NP}$ & 100 & $49.3 \pm 0.57^{*}$ & $1.46 \pm 0.77^{*}$ \\
& 1000 & $49 \pm 0.57^{*}$ & $1.44 \pm 0.64^{*}$ \\
$\mathrm{PC}$ & 6 & $7.66 \pm 1^{*}$ & $0.580 .17^{*}$ \\
\hline
\end{tabular}

The tests were done with 100 seeds/plate, three replicates/treatment. NC: negative control, PC: positive control $\left(\mathrm{ZnSO}_{4} .7 \mathrm{H}_{2} \mathrm{O}\right)$; SG: Seed Germination; RL: Root Length. $\mathrm{M} \pm \mathrm{SD}$ : mean \pm standard deviation. Asterisk indicates significant difference to $\mathrm{NC}$ at $p<0.05$ according to $t$-test.

$\mathrm{TiO}_{2} \mathrm{NP}$ at $1000 \mathrm{mg} / \mathrm{L}$, showing a tendency to increase CA and $\mathrm{MN}$ at $10 \mathrm{mg} / \mathrm{L}$ and $100 \mathrm{mg} / \mathrm{L}$ (Table 2).

The analysis of the different types of CA is shown in Table 3. The main types of CAs were the chromosomal bridge, which was significantly higher than the $\mathrm{NC}$ at 100 and $1000 \mathrm{mg} / \mathrm{L}$ of $\mathrm{TiO}_{2} \mathrm{NPs}$, and chromosomal breaks (significant frequencies for all tested concentrations). Delayed chromosomes, chromosomal adherence, and nuclear buds were also observed in the meristematic cells of $A$. cepa exposed to the $\mathrm{TiO}_{2} \mathrm{NPs}$, and significantly higher frequencies were observed only at the highest tested concentration (1000 mg/L).

These results indicated the genotoxicity, mutagenicity, and cytotoxicity of $\mathrm{TiO}_{2} \mathrm{NPs}$ and were the starting point for complementary tests that confirmed the toxicity of these NPs and allowed to observe what happens inside the cells. All these tests were performed only at the highest concentration $(1000 \mathrm{mg} / \mathrm{L})$, since the objective was the observation of intracellular mechanisms. The results are reported below.

\section{Nucleolar organizer region (NOR) analysis}

Significant increases in the NORs were observed in the $A$. cepa meristematic cells exposed to $\mathrm{TiO}_{2} \mathrm{NP}$ at 1000

Table 2 - Alterations in meristematic cells of Allium cepa exposed to different suspensions of titanium dioxide nanoparticles $\left(\mathrm{TiO}_{2} \mathrm{NP}\right)$.

\begin{tabular}{lcccc}
\hline Treatment & Concentration & $\mathrm{MI}$ & $\mathrm{CA}$ & $\mathrm{MN}$ \\
\hline $\mathrm{MN}$ & $(\mathrm{mg} / \mathrm{L})$ & $\mathrm{M} \pm \mathrm{SD}$ & $\mathrm{M} \pm \mathrm{SD}$ & $\mathrm{M} \pm \mathrm{SD}$ \\
$\mathrm{NC}$ & - & $246.9 \pm 1.55$ & $0.70 \pm 0.67$ & $0.60 \pm 0.69$ \\
$\mathrm{TiO}_{2} \mathrm{NP}$ & 10 & $244.2 \pm 1.75$ & $1.10 \pm 0.73$ & $0.60 \pm 0.69$ \\
& 100 & $240.7 \pm 1.15^{*}$ & $2.19 \pm 0.63$ & $2.39 \pm 0.70$ \\
& 1000 & $236.5 \pm 2.43^{*}$ & $5.28 \pm 1.06^{*}$ & $4.88 \pm 0.88^{*}$ \\
$\mathrm{PC}$ & 10 & $226.5 \pm 1.90^{*}$ & $8.05 \pm 1.44^{*}$ & $33.3 \pm 2.42^{*}$ \\
\hline
\end{tabular}

The tests were done with 5000 cells analyzed per treatment. MI: mitotic index, CA: chromosomal aberrations, $\mathrm{MN}$ : micronuclei, $\mathrm{NC}$ : negative control, $\mathrm{PC}$ : positive control - methyl methane sulfonate. $\mathrm{M} \pm \mathrm{SD}$ : mean \pm standard deviation. Asterisks indicate significant differences at $p<0.05$ compared to NC according to Kruskall-Wallis.
Table 3 - Chromosome aberration (CA) types observed in meristematic cells of $A$. cepa exposed to titanium dioxide nanoparticles $\left(\mathrm{TiO}_{2} \mathrm{NP}\right)$.

\begin{tabular}{lccccc}
\hline CA & \multirow{2}{*}{$\mathrm{NC}$} & \multicolumn{3}{c}{$\mathrm{TiO}_{2} \mathrm{NP}(\mathrm{mg} / \mathrm{L})$} & $\mathrm{PC}$ \\
& & 10 & 100 & 1000 & \\
\hline Clastogenic & & & & & \\
Chromosomal bridge & 0.1 & 0.06 & $0.22^{*}$ & $0.36^{*}$ & $0.66^{*}$ \\
Chromosomal breaks & 0.02 & $0.08^{*}$ & $0.1 *$ & $0.36^{*}$ & $0.48^{*}$ \\
Total & 0.12 & 0.14 & 0.32 & 0.72 & 1.14 \\
Aneugenic & & & & & \\
Chromosomal loss & 0 & 0.02 & 0.02 & 0 & 0.02 \\
Chromosomal delay & 0 & 0 & 0.04 & $0.1 *$ & 0.04 \\
Chromosomal adherence & 0 & 0.02 & 0.06 & $0.16^{*}$ & $0.22^{*}$ \\
Nuclear bud & 0 & 0.04 & 0 & $0.08^{*}$ & $0.12^{*}$ \\
Total & 0 & 0.08 & 0.12 & 0.34 & 0.40 \\
\hline
\end{tabular}

$\mathrm{NC}$ : negative control, PC: positive control - $10 \mathrm{mg} / \mathrm{L}$ methyl methane sulfonate. Data are expressed in frequency (\%). Five thousand cells were analyzed per treatment. Asterisks indicate significant differences at $p<$ 0.05 according to Kruskall-Wallis.

$\mathrm{mg} / \mathrm{L}$ (Figure 2). Moreover, the Ag-NOR staining data show a significant increase in the nucleolar score (1.50 \pm 0.09 in $\mathrm{NC}$ to $1.82 \pm 0.27$ in $\mathrm{TiO}_{2} \mathrm{NP}$ ) and average size of the nucleoli $\left(2221 \pm 159\right.$ in $\mathrm{NC}$ to $2516 \pm 173$ in $\left.\mathrm{TiO}_{2} \mathrm{NP}\right)$ for the $A$. cepa cells exposed to $\mathrm{TiO}_{2} \mathrm{NP}$ compared with the $\mathrm{NC}$ (Student's $t$-test, $p<0.05$ ).

\section{Morpho-anatomical analysis}

The LM analysis showed that the NC meristematic cells are thin-walled and relatively small. These cells contain numerous small vacuoles and large nuclei with one or two nucleoli (Figure 3A,B). With the $\mathrm{TiO}_{2} \mathrm{NP}$ treatment, the nuclei appear more condensed (Figure $3 \mathrm{C}, \mathrm{D}$ ) with up to three nucleoli (Figure 4D) and more and larger vacuoles.

The TEM analysis revealed that the meristematic cells from $\mathrm{NC}$ have organelles with peripheral disposition and a smooth cell wall. Additionally, two types of vacuoles can be characterized: with hyaline content, which are small, rounded, and have lytic vacuoles that have a higher amount of electron-dense material and lenticular shape. Oil bodies, isolated or associated with lytic vacuoles, were also observed in the cytoplasm of NC cells.

Rupture of the plasma membrane and a large number of oil bodies with peripheral disposition were observed in cells exposed to $\mathrm{TiO}_{2} \mathrm{NP}(1000 \mathrm{mg} / \mathrm{L})$ (Figure 4B-E). In addition, A. cepa meristematic cells exposed to $\mathrm{TiO}_{2} \mathrm{NP}$ also exhibited a greater number of lytic vacuoles, which were larger (Figure 4E) compared to NC.

\section{Selected area electron diffraction (SAED)}

The electron diffraction analysis performed in $A$. cepa roots exposed to $1000 \mathrm{mg} / \mathrm{L}$ of $\mathrm{TiO}_{2} \mathrm{NPs}$ revealed the presence of $\mathrm{TiO}_{2} \mathrm{NPs}$ inside lytic vacuoles in $A$. cepa cells. These particles had an approximate size of $450 \mathrm{~nm}$ and, ac- 

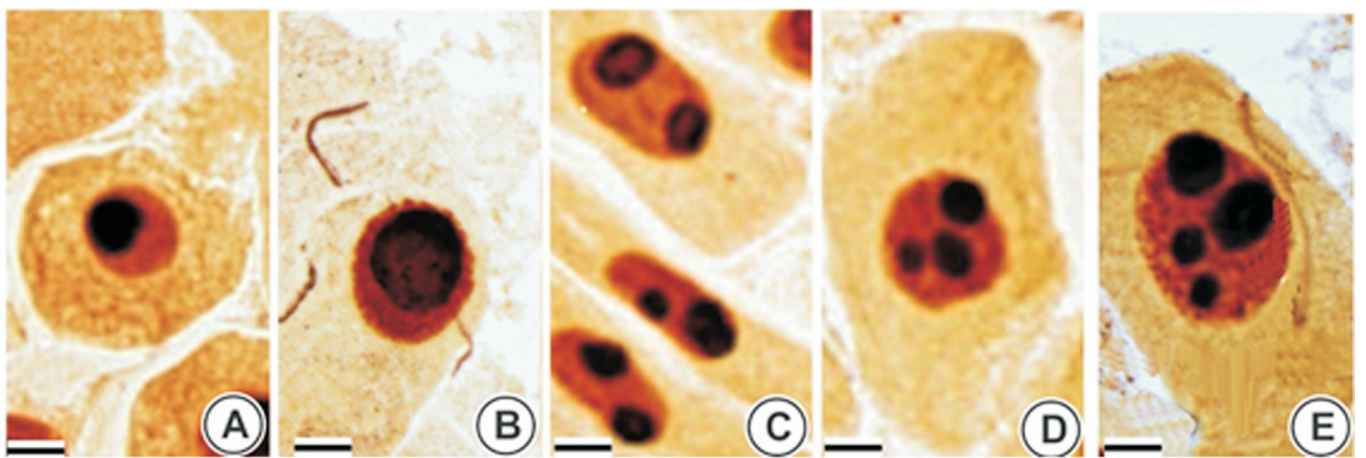

Figure 2 - Meristematic cells of Allium cepa germinated in the negative control (NC) and $1000 \mathrm{mg} / \mathrm{L} \mathrm{TiO}{ }_{2} \mathrm{NP}$ subjected to Ag-NOR staining and banding. (A) Nucleoli germinated in NC, (B-E) cells germinated in $1000 \mathrm{mg} / \mathrm{L} \mathrm{TiO}_{2} \mathrm{NP}$, (B) increased size nucleoli, (C) two nucleoli, (D) three nucleoli, (D) four nucleoli. Scale bars $20 \mu \mathrm{m}$.

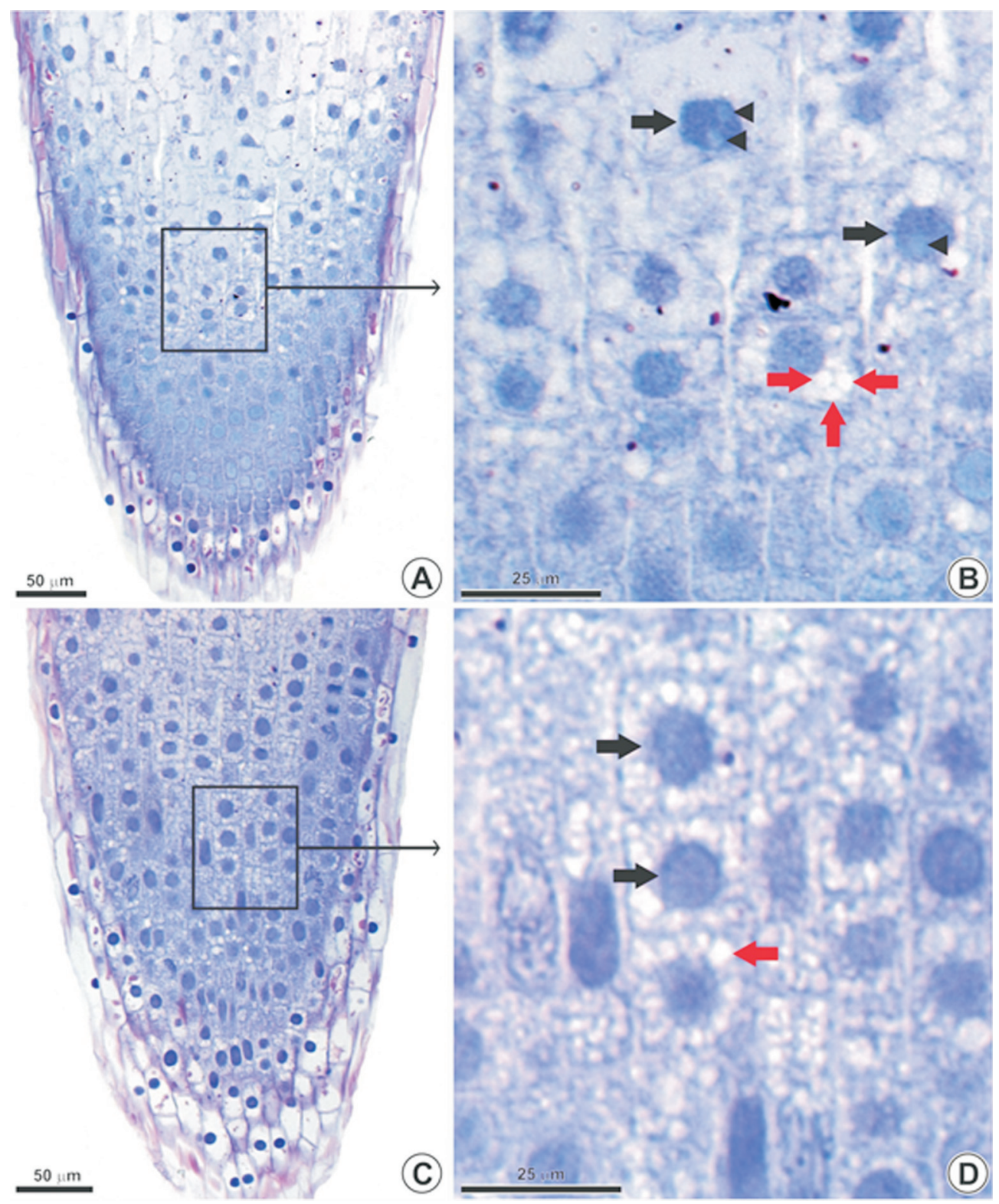

Figure 3 - Root tip of Allium cepa (longitudinal sections) observed in light microscope. Negative control (A-B) and group exposed to $1000 \mathrm{mg} / \mathrm{L}$ TiO $\mathrm{O}_{2} \mathrm{NP}$ (C-D). (A) Control root tip. (B) Selected region of the apical root meristem in A/B. (C) $1000 \mathrm{mg} / \mathrm{L} \mathrm{TiO}_{2} \mathrm{NP}$. (D) Selected region of the apical root meristem in C/D. Black arrow: nuclei; black arrowhead: nucleoli in evidence; red arrow: vacuoles increased in volume and number. 

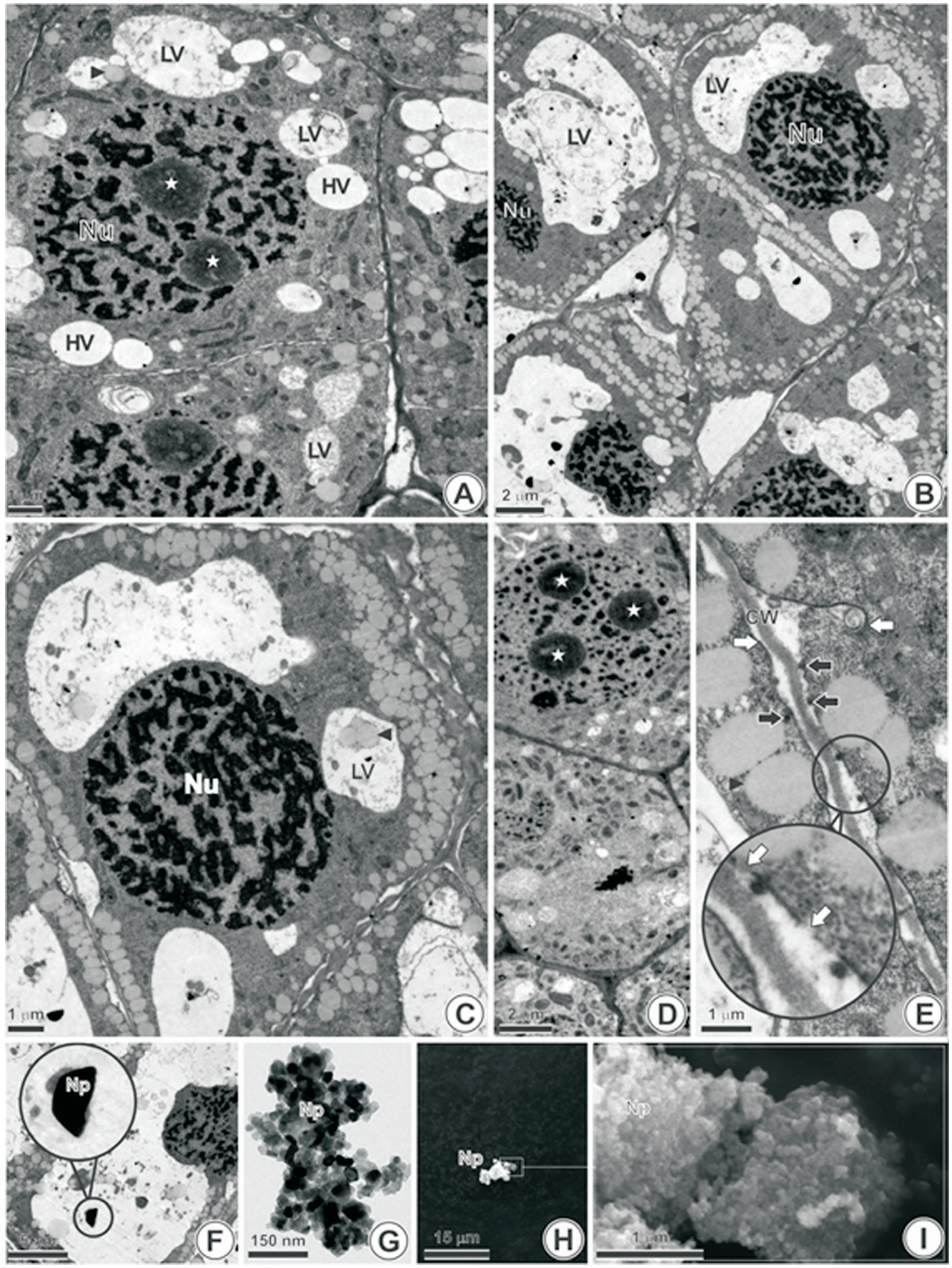

Figure 4 - Root tip of Allium cepa (longitudinal sections) observed in transmission electron microscope. (A) Negative control and cells exposed to 1000 $\mathrm{mg} / \mathrm{L} \mathrm{TiO}_{2} \mathrm{NP}$ (B-E). Suspension of $1000 \mathrm{mg} / \mathrm{L} \mathrm{TiO}_{2} \mathrm{NP}$ observed by selected area electron diffraction analysis (SAED) in transmission electron microscope (F-G) and scanning microscope (H-I). (A) Cell with lytic vacuole (LV) and hyaline (HV), and nucleus (Nu) with two nucleoli (star). (B) Increase in the volume and number of lytic vacuoles and increased volume of oil bodies (arrowhead). (C) Large number of oil bodies (arrowhead) in the adjacencies of plasma membrane and within the lytic vacuoles. (D) Nucleus with three nucleoli (star). (E) Rupture of the plasma membrane (white arrow) and electron-dense corpuscles associated with the plasma membrane (black arrow). Abbreviations: $\mathrm{CW}$ (cell wall). (F) Internalized $\mathrm{TiO}_{2} \mathrm{NP}$ in the vacuole with $450 \mathrm{~nm}$ in the brookite phase. $(\mathrm{G})$ Characterization of the $\mathrm{TiO}_{2} \mathrm{NP}$ suspension in TEM. (H) Characterization of $\mathrm{TiO}_{2} \mathrm{NP}_{\text {in }}$ scanning microscope - 500x. (I) Characterization of $\mathrm{TiO}_{2} \mathrm{NP}$ in scanning microscope, 50,000 x. 
Table 4 - Analysis by selected area electron diffraction (SAED) in suspension and inside cells of $A$. cepa roots exposed to $1000 \mathrm{mg} / \mathrm{L} \mathrm{TiO}_{2} \mathrm{NP}$.

\begin{tabular}{lcccc}
\hline Material & Profile & $\mathrm{D}_{\text {measured }}(\mathrm{nm})$ & $\mathrm{D}_{\text {tabulated }}(\mathrm{nm})$ & $\Delta(\%)$ \\
\hline & & & Brookite phase & \\
& 1 & $0.268 \pm 0.04$ & 0.2728 & -1.75 \\
$\begin{array}{l}\text { In } \text { A. cepa } \\
\text { roots cells }\end{array}$ & 1 & $0.132 \pm 0.01$ & 0.1335 & -1.12 \\
& 2 & $0.268 \pm 0.04$ & 0.2669 & +0.41 \\
& 2 & $0.133 \pm 0.01$ & 0.1335 & -0.37 \\
& 3 & $0.228 \pm 0.03$ & 0.2295 & -0.65 \\
& 3 & $0.154 \pm 0.02$ & 0.1530 & +0.65 \\
& & & Anatase phase & \\
& 1 & $0.344 \pm 0.004$ & 0.352 & -2.3 \\
Nanopowder & 3 & $0.237 \pm 0.002$ & 0.2378 & -0.3 \\
form & 4 & $0.185 \pm 0.001$ & 0.1892 & -2.2 \\
& 5 & $0.0934 \pm 0.0005$ & 0.09464 & -1.3 \\
& 6 & $0.0853 \pm 0.0004$ & 0.08464 & +0.8 \\
\hline
\end{tabular}

$\mathrm{D}_{\text {measured }}$ values are compared with $\mathrm{D}_{\text {tabulated }}$ values and from the difference $(\Delta)$ percentage, the phase identification is performed.

cording to the analysis of interplanar spacing and orthorhombic format, they were in the brookite phase. On the other hand, the SAED nanopowder analysis confirmed the manufacturer information saying that the $\mathrm{TiO}_{2} \mathrm{NP}$ in the powder form was $100 \%$ anatase phase and with an average size of $25 \mathrm{~nm}$. Table 4 shows the interplanar distances (d) obtained through the analysis performed on the A. серa roots and in the nanopowder form. Figure $4 \mathrm{~F}-\mathrm{I}$ shows the images of this analysis, and Figure 5 shows the two forms of $\mathrm{TiO}_{2} \mathrm{NP}$ (anatase and brookite phases).

\section{Discussion}

Most of the phytotoxicity studies of $\mathrm{TiO}_{2} \mathrm{NPs}$ do not comprise a characterization of their suspensions (e.g., $\mathrm{TiO}_{2} \mathrm{NPs}$ suspensions), and only characterize the nano- powder (Ghosh et al., 2010; Klancnik et al., 2010; Kumari et al., 2011; Pakrashi et al., 2014). There is an imminent demand to elucidate the mechanisms of toxicity of NPs in plants in order to protect these key organisms of terrestrial and aquatic ecosystems, as they are the base of the food chain and support several ecosystems services, such as pollination. Within this context, the knowledge of NPs toxicity mechanisms can be better achieved when nanotoxicological studies include information about the features of NPs in suspension (Schwab et al., 2016).

When in aqueous media, the $\mathrm{pH}$ of samples is considered one of the most important factors that may alter the values of the zeta potential (Jiang and Oberdorster, 2009). Zeta potential $(\zeta)$ is the measurement of the particle potential at the surface of the hydrodynamic shear. In this study, when analyzing the zeta potential values, all the suspensions presented instability in their colloidal systems, facilitating the formation of particle aggregates, even after sonication of these suspensions. Besides that, regarding the zeta potential, the existence of a $\mathrm{pH}$ value in which the values of the negative and positive charges are present in the same amount around the particles is known as point of zero charge $\left(\mathrm{pH}_{\mathrm{pzc}}\right)$. The $\mathrm{pH}_{\mathrm{pzc}}$ of $\mathrm{TiO}_{2} \mathrm{NPs}$ in anatase phase is pH 6.3 (Finnegan et al., 2007). In this case, $\mathrm{TiO}_{2} \mathrm{NP}$ is considered an acidic metal oxide, which means that its highly hydroxylated surface tends to donate protons by dissociating water, binding the $\mathrm{OH}^{-}$ions and releasing $\mathrm{H}^{+}$ions, leaving these NPs positively charged. Our $\mathrm{TiO}_{2} \mathrm{NPs}$ suspensions, at the highest concentration $(1000 \mathrm{mg} / \mathrm{L})$, whose $\mathrm{pH}$ was measured as 4.90 , probably showed many particles with positive charges, which make the entrance of these NPs into cells possible by passing cell membranes. Additionally, the high polydispersity index of $\mathrm{TiO}_{2} \mathrm{NPs}$ in the three concentrations tested in this study, allowed the observation of particles of different sizes. This information is important because it indicates that particle size is not homogeneous, which may explain the damage caused by $\mathrm{TiO}_{2} \mathrm{NPs}$, considering the existence of particles at the nanoscale.

Phytotoxicity is usually estimated by the seed germination and root elongation toxicity test. Our findings
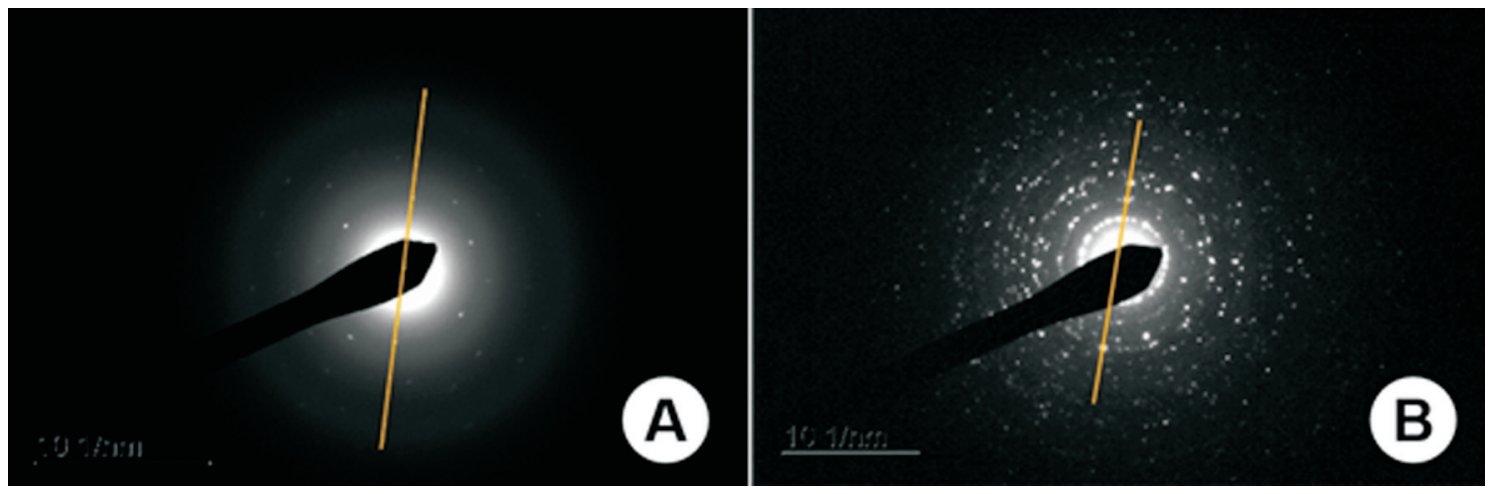

Figure 5 - Selected area electron diffraction (SAED) pictures used in the calculation of interplanar distances. (A) $\mathrm{TiO}_{2}$ in brookite phase inside the roots of A. cepa. (B) $\mathrm{TiO}_{2}$ in anatase phase in nanopowder form used in this experiment. 
showed that $\mathrm{TiO}_{2} \mathrm{NPs}$ slightly inhibited seed germination and root growth; however, cellular and genetic damages were observed to meristematic cells of $A$. сера after $\mathrm{TiO}_{2} \mathrm{NP}$ exposure. Studies have pointed out that determination of phytotoxicity by macroscopic parameters is not always accurate (Lin and Xing, 2007; Klancnik et al., 2010; Castiglione et al., 2016; Cox et al., 2017), and genotoxicological analysis is required to predict the hazards of chemicals.

DNA damages to plant cells after NP exposure have been reported (Klancnik et al., 2010; Kumari et al., 2011; Pakrashi et al., 2014; Castiglione et al., 2016). In this study, increased frequencies of $\mathrm{CA}$ and $\mathrm{MN}$ in concentrationdependent manner were observed in A.cepa meristematic cells exposed to $\mathrm{TiO}_{2} \mathrm{NPs}$, indicating their internalization. In addition, different types of CA were found. Significant values of clastogenic CAs (e.g., chromosome breaks and bridges) were observed in all tested concentrations, while aneugenic CAs (e.g., chromosome delay, chromosome adhesion, and nuclear buds) could be detected only at the highest concentration tested $(1000 \mathrm{mg} / \mathrm{L})$.

Chromosomal bridges result from structural changes between sister chromatids or between different chromosomes due to breaks or terminal deletions. Bridges that persist at the end of anaphase can originated chromosomal fragments (i.e., breaks) during chromatin segregation (Humphrey and Brinkley, 1969). Chromosome breaks can also be caused by external agents, affecting the dynamics of the chromatin, and may damage the repair process (Terzoudi et al., 2011).

Impairment of the mitotic spindle apparatus may lead to chromosomal adherences (Ventura-Camargo et al., 2011). Adherence is an irreversible abnormality that involves the proteinaceous matrix of chromatin rather that DNA itself, usually leading to cell death (Fiskesjo, 1988). The interruption in mitotic spindle polymerization may promote a unilateral binding of the fuse to chromosomes, making their movement to the poles unfeasible and leading to chromosomal losses (Shamina et al., 2003).

Chromosomal losses and breaks can originate in micronuclei and be from an aneugenic or clastogenic origin, while nuclear buds may originate from nuclear envelope formation prior to complete chromosome migration to the poles and their incorporation into the nuclei, as well as by cellular activities that promote the elimination of the amplified genetic material (Mazzeo et al., 2011).

These genotoxicity results stimulated the accomplishment of complementary tests that allowed the observation of $\mathrm{TiO}_{2} \mathrm{NPs}$ internalization, which corroborated the toxicity results of this NP. These complementary tests were performed only with the highest concentration, because we aimed to understand $\mathrm{TiO}_{2} \mathrm{NPs}$ internalization and observe their effects. The significant increase in nucleolar score, as well as their sizes, in A. cepa interphase cells exposed to $1000 \mathrm{mg} / \mathrm{L} \mathrm{TiO}_{2} \mathrm{NP}$ suggests that these results are due to an increase in genome activity (Mazzeo and Marin-Morales, 2015). According to Boulon et al. (2010), nucleoli are apparently major structures involved in the activation of cellular stress. Increased nucleoli volume suggests gene amplification and may be another indicative of genotoxicity (Mazzeo and Marin-Morales, 2015).

The cellular damage observed in A. cepa cells exposed to $\mathrm{TiO}_{2} \mathrm{NPs}$ indicates that this NP was taken up by the meristematic cells, causing deleterious effects. This study demonstrated that NPs were internalized by the meristematic cells of $A$. cepa. This internalization probably occurred due to the excess of positively charged particles that were easily attracted and internalized by the plasma membrane (negatively charged), allowing the observation of negative effects in these cells. These data agree with other studies of NPs (zinc oxide NPs and $\mathrm{TiO}_{2} \mathrm{NPs}$ ) (Kumari et al., 2011; Larue et al., 2012), in which the authors also reported that NP uptake may result in damages from cellular defense mechanisms. The present results indicate that roots exposed to $\mathrm{TiO}_{2} \mathrm{NPs}$ show damage to both the plasma membrane and cell wall, suggesting that these barriers are not effective against $\mathrm{TiO}_{2} \mathrm{NP}$ uptake by meristematic cells.

Once the structure and function of both the cell wall and plasma membrane have been compromised, a physical barrier was formed by oil bodies located beneath them to reduce the uptake of $\mathrm{TiO}_{2} \mathrm{NPs}$. According to Zhao et al. (2016), the increased number of oil bodies may indicate a cellular defense mechanism against toxicants. Moreover, a rise in the number and size of lytic vacuoles in the cytoplasm may also be related to this cellular defense mechanism, since this cellular compartment acts as a primary deposit site of toxic compounds (Ma et al., 2015). Defense mechanisms are common when the plant encounters an adverse situation, like an exposure to a contaminant (Medina et al., 2016; Car et al., 2019). The SAED analysis showed the presence of $\mathrm{TiO}_{2} \mathrm{NPs}$ in lytic vacuoles of $A$. cepa meristematic cells that were exposed to this agent, as well as in Triticum aestivum $\mathrm{spp}\left(\mathrm{TiO}_{2} \mathrm{NPs}\right.$ at $\left.100 \mathrm{mg} / \mathrm{L}\right)$, as observed by Larue et al. (2012).

The TEM analysis carried out on A. cepa cells exposed to $1000 \mathrm{mg} / \mathrm{L} \mathrm{TiO}_{2} \mathrm{NP}$ showed that the deposit of this NP in lytic vacuoles occurs in aggregates of ca. $450 \mathrm{~nm}$. The SAED results showed an orthorhombic structure compatible with the brookite phase, differently from a tetragonal structure expected for the anatase phase. This finding suggests that $\mathrm{TiO}_{2} \mathrm{NPs}$ were taken up by the cells and that a phase change had occurred (anatase to brookite).

According to the literature, the anatase and brookite phases are metastable and can switch their shape (Alotaibi et al., 2018). The phase change showed in this work can be related to cellular defense mechanisms, as an attempt to minimize the damages caused by the internalized $\mathrm{TiO}_{2} \mathrm{NPs}$. Therefore, the anatase to brookite phase conversion would be a way to "mitigate" the deleterious effects of $\mathrm{TiO}_{2} \mathrm{NPs}$ probably by reducing the damage mediated by reactive ox- 
ygen species (Larue et al., 2012). It can be hypothesized that the interaction with biological molecules (e.g., enzymes) produced by the plant system may be the responsible factor for the phase change (anatase to brookite) caused by $\mathrm{TiO}_{2} \mathrm{NPs}$ in $A$. cepa meristematic cells. However, further studies are needed to elucidate the crystalline phase change of $\mathrm{TiO}_{2} \mathrm{NPs}$ inside plant cells.

Finally, A. серa was shown to be sensitive to the genotoxic and cytotoxic effects of $\mathrm{TiO}_{2} \mathrm{NPs}$, thus being a suitable test system for predicting the hazard potential of NPs to plants. To minimize the toxic effects of $\mathrm{TiO}_{2} \mathrm{NPs}$, plant cells exhibit cellular defense mechanisms that include increasing the number of oil bodies and lytic vacuoles. Furthermore, phase transformation of the crystal structure from anatase to brookite may also be an attempt to mitigate the toxic potential of $\mathrm{TiO}_{2} \mathrm{NPs}$. In spite of the defense mechanisms, these NPs are still able to induce severe damages at nuclear (genotoxicity; changes in the nucleolar pattern) and cellular levels (cytotoxicity) in a concentrationdependent manner, which is indicative of their internalization. Probably, NPs were taken up by the meristematic cells through disruption of physical barriers (plasma membrane and cell wall). The phase conversion of $\mathrm{TiO}_{2} \mathrm{NPs}$ from anatase to brookite inside a plant cell was reported here for the first time, but the mechanisms associated with this change need to be elucidated by further studies.

\section{Acknowledgments}

This study was financed in part by the Coordenação de Aperfeiçoamento de Pessoal de Nível Superior - Brasil (CAPES) - Finance Code 001, and CNPq (Brazilian Agency for Science and Technology). The authors would like also to thank the Multi-User Confocal Microscopy Center of the Federal University of Paraná for the help in carrying out this research.

\section{Conflicts of interest}

The authors declare that there are no conflicts of interests.

\section{Author contributions}

RSF, TV, MMC and DML conceived and designed the study, analyzed the data and wrote the manuscript. RSF and TV conducted the experiments. KF helped to perform the genotoxicological test. NM performed the Selected area electron diffraction analysis. BFS and SSA performed the Morpho-anatomical analysis and wrote the manuscript. All authors read and approved the final version.

\section{References}

Aguiar TV, Sant'anna-Santos BF, Azevedo AA and Ferreira RS (2007) Anati Quanti: Quantitative analysis software for plant anatomy studies. Planta Daninha 2:649-659.
Alotaibi AM, Sathasivam S, Williamson BAD, Kafizas A, Sotelo-Vazquez C, Taylor A, Scanlon DO and Parkin IP (2018) Chemical vapor deposition of photocatalytically active pure brookite $\mathrm{TiO}_{2}$ thin films. Chem Mat 30:1353-1361.

Boulon S, Westman BJ, Hutten S, Boisvert FM and Lamond AI (2010) The nucleolus under stress. Mol Cell 40:216-227.

Car JP, Murphy AM, Tungadi T and Yoon JY (2019) Plant defense signals. Players and pawns in plant-virus-vector interactions. Plant Science 279:87-95

Castiglione MR, Giorgetti L, Bellani L, Muccifora S, Bottega S and Spano C (2016) Root responses to different types of $\mathrm{TiO}_{2}$ nanoparticles and bulk counterpart in plant model system Vicia faba L. Environ Exp Bot 130:11-21.

Clement L, Hurel C and Marmier N (2013) Toxicity of $\mathrm{TiO}_{2}$ nanoparticles to cladocerans, algae, rotifers and plants - effects of size and crystalline structure. Chemosphere 90:1083-1090.

Cox A, Venkatachalam P, Sahi S and Sharma N (2017) Reprint of silver and titanium dioxide nanoparticle toxicity in plants: A review of current research. Plant Physiol Biochem 110:3349.

Dourado PLR, Rocha MP, Roveda LM, Raposo-Junior JL, Candido LS, Cardoso CAL Marin-Morales MA, Oliveira KMP and Grisolia AB (2017) Genotoxic and mutagenic effects of polluted surface water in the midwestern region of Brazil using animal and plant bioassays. Genet Mol Biol 40:123-133.

Finnegan MP, Zhang H and Banfield JF (2007) Phase stability and transformation in titania nanoparticles in aqueous solutions dominated by surface energy. J Phys Chem C 111:19621968.

Fiskesjo G (1985) The Allium test as a standard in environmental monitoring. Hereditas 102:99-112.

Fiskesjo G (1988) Allium Test - An alternative in environmental studies: the relative toxicity of metal ions. Mutation Research 197:243-260

Ghosh M, Bandyopadhyay M and Mukherjee A (2010) Genotoxicity of titanium dioxide $\left(\mathrm{TiO}_{2}\right)$ nanoparticles at two trophic levels: Plant and human lymphocytes. Chemosphere 81:1253-1262.

Grisolia CK, Oliveira ABB, Bonfim H and Klautau-Guimarães MN (2005) Genotoxicity evaluation of domestic sewage in a municipal wastewater treatment plant. Genet Mol Biol 28:334-338.

Humphrey RM and Brinkley BR (1969) Ultrastructural studies of radiotion induces chromosome damage. J Cell Biol 42:745753.

Jiang J and Oberdorster G (2009) Characterization of size, surface charge, and agglomeration state of nanoparticle dispersions for toxicological studies. J Nanoparticle Res 11:77-89.

Karnovsky MJ (1965) A formaldehyde-glutaraldehyde fixative of high osmolarity for use in electron microscopy. J Cell Biol 27:137-138.

Klancnik K, Drobne D, Valant J and Koce JD (2010) Use of a modified Allium test with nano $\mathrm{TiO}_{2}$. Ecotoxicol Environ Saf 74:85-92.

Kumari M, Khan SS, Pakrashi S, Mukherjee A and Chandrasekaran N (2011) Cytogenetic and genotoxic effects of zinc oxide nanoparticles on root cells of Allium cepa. J Hazard Mater 190:613-621.

Larue C, Laurette J, Herlin-Boime N, Khodja H, Favard B, Flank A, Brisset F and Carriere M (2012) Accumulation, trans- 
location and impact of $\mathrm{TiO}_{2}$ nanoparticles in wheat: Influence of diameter and crystal phase. Sci Total Environ 431:197-208.

Leme DM and Marin-Morales MA (2008) Chromosome aberration and micronucleus frequencies in Allium cepa cells exposed to petroleum polluted water - a case study. Mutat Res 650:80-86.

Leme DM and Marin-Morales MA (2009) Allium cepa test in environmental monitoring: A review on its application. Mutat Res 682:71-81.

Leme DM, Angelis DF and Marin-Morales MA (2008) Action mechanisms of petroleum hydrocarbons present in waters impacted by an oil spill on the genetic material of Allium cepa roots cells. Aquat Toxicol 88:214-219.

Lin D and Xing B (2007) Phototoxicity of nanoparticles: Inhibition of seed germination and root growth. Environ Pollut 150:243-250.

Ma C, White JC, Dhankher OP and Xing B (2015) Metal-based nanotoxicity and detoxification pathways in higher plants. Environ Sci Technol 49:7109-7122.

Ma X, Lee JG, Deng Y and Kolmarkov A (2010) Interactions between engineered nanoparticles (ENPs) and plants: phytotoxicity, uptake and accumulation. Sci Total Environ 408:3053-3061.

Mazzeo DEC and Marin-Morales MA (2015) Genotoxicity evaluation of environmental pollutants using analysis of nucleolar alterations. Environ Sci Pollut Res 22:9766-9806.

Mazzeo DE, Fernandes TC and Marin-Morales MA (2011) Cellular damages in the Allium cepa test system, caused by BTEX mixture prior and after biodegradation process. Chemosphere 85:13-18.

Medina AM, Flors V, Heil M, Mani BM and Pieterse CMJ (2016) Recognizing plant defense priming. Trends Plant Sci 21:812-822.

Mello MLS and Vidal BC (1978) A reação de Feulgen. Ciênc Cult 30:665-676.

Monica RC and Cremonini R (2009) Nanoparticles and higher plants. Caryologia 62:161-165.

O'Brien PP and McCully ME (1981) The study of plants structure principles and selected methods. Termarcarphi Pty, Melbourne, $345 \mathrm{pp}$.

Pakrashi S, Jain N, Dalai S, Jayakumar J and Chandrasekaran PT (2014) In vivo genotoxicity assessment of titanium dioxide nanoparticles by Allium cepa root tip assay at high exposure concentrations. PLoS One 9:e87789
Passoni S, Pires LF, Saab SDC and Cooper M (2014) Software Image $\mathrm{J}$ to study soil pore distribution. Ciênc Agrotecnol 38:122-128.

Rank J (2003) The method of Allium anaphase-telophase chromossome aberration assay. Ekologija 1:38-42.

Reynolds E (1963) The use of lead citrate at high pH as an electron-opaque stain in electron microscopy. J Cell Biol 17:208-212.

Robichaud CO, Uyar AE, Darby MR, Zucker LG and Wiesner MR (2009) Estimates of upper bounds and trends in nano$\mathrm{TiO}_{2}$ production as a basis for exposure assessment. Environ Sci Technol 43:4227-4233.

Rodrigues FP, Angeli JPF, Mantovani MS, Guedes CLB and Jordão BQ (2010) Genotoxic evaluation of an industrial effluent from an oil refinery using plant and animal bioassays. Genet Mol Biol 33:169-175.

Schwab F, Zhai G, Kern M and Turner A (2016) Barriers, pathways and processes for uptake translocation and accumulation of nanomaterials in plants - critical review. Nanotoxicology 10:1-22.

Shamina NV, Silkova OG and Seriukova EG (2003) Monopolar spindles in meiosis of intergeneric cereal hybrids. Cell Biol Int 27:657-664.

Terzoudi GI, Hatzi VI, Bakoyianni CD and Pantelias GE (2011) Chromatin dynamics during cell cycle mediate conversion of DNA damage into chromatid breaks and affect formation of chromosomal aberrations: Biological and clinical significance. Mutat Res 711:174-186.

Ventura-Camargo BC, Maltempi PPP and Marin-Morales MA (2011) The use of the cytogenetics to identify mechanisms of action of an azo dye in Allium cepa meristematic cells. $\mathrm{J}$ Environ Analyt Toxicol 1:1-12

Zhao L, Chen Y, Chen Y, Kong X and Hua Y (2016) Effects of pH on protein components of extracted oil bodies from diverse plant seeds and endogenous protease-induced oleosin hydrolysis. Food Chem 200:125-133.

Zhu X, Chang Y and Chen Y (2010) Toxicity and bioaccumulation of $\mathrm{TiO}_{2}$ nanoparticles aggregates in Daphnia magna. Chemosphere 78:209-215.

\section{Internet resources}

Malvern (2015) A basic guide to particle characterization, http://www.malvern.com/en/ (accessed 10 September 2015).

\section{Associate Editor: Daisy Maria Fávero Salvadori}

License information: This is an open-access article distributed under the terms of the Creative Commons Attribution License (type CC-BY), which permits unrestricted use, distribution and reproduction in any medium, provided the original article is properly cited. 